\title{
David Oliver: A mandate for mismanagement
}

\author{
David Oliver, consultant in geriatrics and acute general medicine
}

Berkshire

The 2015 Conservative election manifesto committed to make England "the first nation in the world to have a genuinely seven day NHS," including "seven day a week access for everyone to a GP" and "hospitals properly staffed, so that the quality of care is the same every day of the week."

Conservative ministers, government communications teams, and some journalists have repeatedly argued that the outright election victory has given the party an "electoral mandate" to govern, albeit in a system where only $37 \%$ of the electorate voted for it. ${ }^{2}$ They maintain that electoral victory also represents a mandate for specific election pledges, such as those made on health.

Junior doctors and consultants have protested against imposing contracts on staff who already work at weekends and cannot contractually opt out of doing so. ${ }^{3}$ GPs, hospital doctors, and nurses have highlighted their serious workforce and funding crises and the high number of unfilled posts..$^{4-6}$ Major cuts in social care funding have affected delivery and spending on the NHS. ${ }^{7}$ Performance is tailing off, even in existing weekday service provision, as demand rises. ${ }^{8}$

No matter, say defenders of the government's stance. They have an electoral mandate: they are pushing ahead, and criticising policy means that people are less committed to quality services than the politicians.

The education secretary, Nicky Morgan, recently defended a policy of forcing all schools-primary and secondary, good and poor - to become academies. ${ }^{9}$ But this was not pledged in the manifesto of only a year before. ${ }^{1}$ No mandate there, then.

Nor did it include any such pledge to slash benefits to disabled people by a further $£ 4.4 \mathrm{bn}$, as announced in the 2016 budget. $^{10}$ If the manifesto is a manual for electoral legitimacy, just read it.

And there was no mandate in the 2010 election for Andrew Lansley's 2012 Health and Social Care Act, now pretty universally regarded as a costly, unnecessary train wreck, even by Conservatives. ${ }^{11}$ Indeed, it breached a mandate for "no top-down reorganisation." 12

The 2015 Tory manifesto did include a mandate to implement a cap on long term social care costs, as recommended by the
Dilnot Commission report ${ }^{13}$; the party reneged and delayed it until at least 2020. And there was no mandate to cut public health budgets by $£ 200 \mathrm{~m}$ despite manifesto pledges to "help you and your family to stay healthy."14

The truth is that mandates require realistic plans and competent delivery: a costed, funded, staffed, and risk assessed government programme for implementation. Soundbites won't cut it. And delivery requires engaged, motivated frontline staff, so why is the government antagonising and demoralising them?

\section{Competing interests: See www.bmj.com/about-bmj/freelance- contributors/david-oliver.}

Provenance and peer review: Commissioned; not externally peer reviewed.

1 Conservative Party. Strong leadership, a clear economic plan, a brighter, more secure future: 2015 manifesto. https://s3-eu-west-1.amazonaws.com/manifesto2015/ ConservativeManifesto2015.pdf.

2 Garland J, Terry C. The 2015 general election: a voting system in crisis. Electoral Reform Society. Jun 2015. Available at www.electoral-reform.org.uk/publications.

3 Cooper C. Doctors declare war on Jeremy Hunt over weekend working "myths" amid plan for seven day NHS. Independent 2015 Jul 31. www.independent.co.uk/life-style/healthand-families/health-news/doctors-declare-war-on-jeremy-hunt-over-weekend-working myths-10431783.html.

4 Bostock N. General practice faces "biggest workforce crisis since its inception," warn LMCs. GP 2015 May 1. www.gponline.com/general-practice-faces-biggest-workforcecrisis-its-inception-warn-Imcs/article/1345659.

5 Campbell D. Hospital staffing crisis as $40 \%$ of consultant posts remain vacant. Guardian 2016 Mar 15. www.theguardian.com/society/2016/mar/15/hospital-staffing-crisis-consultantposts-remain-vacant.

6 Hughes D, Clarke V. Thousands of NHS nursing and doctor posts lie vacant. BBC News $2016 \mathrm{Feb} 29$. www.bbc.co.uk/news/health-35667939.

7 Trust N. Health Foundation, King's Fund. Impact of the 2015 spending review on health and social care. 2016. http://bit.ly/22eGkG3.

8 King's Fund. Quarterly monitoring report 18. Feb 2016. http://qmr.kingsfund.org.uk/2016/ $18 /$.

9 Sellgren K. Teachers shout "rubbish" at Morgan's academy plans. BBC News 2016 Mar 26. www.bbc.co.uk/news/education-35899478.

10 Stone J. PIP cuts: the disability benefit cuts that sparked a Tory civil war. Independent 2016 Mar 21. www.independent.co.uk/news/uk/politics/disability-benefit-cuts-what-is-pipu-turn-george-osborne-why-a6943976.html.

11 Helm T. Health reform is our biggest mistake in this parliament, says Tory ex-minister. Guardian 2015 Jan 31. www.theguardian.com/politics/2015/jan/31/health-reform-toriesbiggest-mistake-parliament-nhs-stephen-dorrell-mp.

12 Timmins N. King's Fund, Institute for Government. Never again? The story of the Health and Social Care Act 2012. Jul 2012. www.instituteforgovernment.org.uk/sites/default/files/ publications/Never\%20again_0.pdf.

13 King's Fund. The first hundred days-summary: social care. 17 Aug 2015. www.kingsfund. org.uk/projects/new-gov/social-care.

14 Buck D. Cuts to public health spending: the falsest of false economies. King's Fund blog. 6 Aug 2015. www.kingsfund.org.uk/blog/2015/08/cuts-public-health-spending-falsestfalse-economies. 
Published by the BMJ Publishing Group Limited. For permission to use (where not already granted under a licence) please go to http://group.bmj.com/group/rights-licensing/

permissions 